\title{
Austere creativity and volunteer-run public services: the case of Lewisham's Libraries Kirsten Forkert
}

\begin{abstract}
The article explores a particular concept of creativity that which is being mobilised within Austerity Britain. This mobilisation involves capitalising on the resourcefulness and ingenuity of citizens in their ability to adapt and 'problem-solve' in the face of cuts to the welfare state; it lacks any oppositional or explicitly political aspects. Such a conception of creativity is also linked to imperatives to restore a perceived loss of community and authentic experience, and to the nostalgic belief that austerity provides an opportunity to do so by bringing us 'back to basics'. 'Austere creativity' becomes prevalent in the absence of alternatives and large-scale social movements challenging austerity. The article will explore these issues through the case of a campaign to save five libraries in Lewisham, London in 2010-11, and in the reaction of campaigners to the decision by the council to turn them over to charities and social enterprises, with volunteers replacing qualified librarians. It is based on interviews with key activists, ethnographic observations from the author's role as an activist in the campaign, grey literature and a promotional video on the outsourcing of public services.
\end{abstract}

Keywords: austerity, creativity, cuts, activism, libraries, UK, Big Society, Lewisham, social movements, cultural policy

\section{Introduction}

The article will explore the mobilization of the concept of 'creativity' within the austerity context; stripped of any oppositional or transgressive aspects, it is used to mean the resourcefulness and ingenuity of citizens to adapt and 'problem-solve' in the face of cuts to the welfare state. Such a conception of creativity involves the co-option and privatisation of impulses towards self-organisation and libertarian critiques of the welfare state. It was also linked to imperatives to restore a perceived lost sense of community, and to the conviction that austerity provides the opportunity to do so by forcing citizens to rely on each other rather than the state. This 'austere creativity' is important to consider as an aspect of the wider cultural politics of austerity.

'Austere creativity' will be examined through the case of the campaign against the closure of five libraries in Lewisham, London, in 2011 and the reaction of campaigners to their eventual conversion to social enterprises and charities with volunteers replacing qualified librarians. The case reflects the impasses intrinsic to anti-austerity campaigns, in which one is often faced with a defence of existing public service provision which does not really satisfy desires for an alternative. These impasses make it easy to claim, as will be seen, that the conversion would foster both a sense of community and creativity not possible under council ${ }^{1}$ ownership.

The article will begin by examining the instrumentalisation of the concept of 'creativity' within neoliberal policy discourses before the financial crisis, and will consider its application within the austerity context. I will then discuss the case of the 2010-2011 campaign to save the libraries in Lewisham. The article will be based on three in-depth, semi-structured interviews with key activists involved in the libraries campaign, as well as auto-ethnographic observations on my own involvement as an activist. Grey literature on the outsourcing of public services and a promotional video about the volunteer-run library will also be examined.

\section{Neoliberal creativity}

I will first offer a brief genealogy of the discourse of 'creativity' as it has been used within neoliberal

\footnotetext{
${ }^{1}$ The council is the elected municipal legislature for a borough or county.
} 
policy discourse. This will first be discussed within a global framework, and then will focus on the UK, particularly within the context of austerity. From the late 1990s until the financial crisis, there were utopian promises in cultural, urban and employment policy about how creative work and creativity itself could lift people out of poverty, fix economies, and provide work satisfaction: a certain 'magic bullet solution'. ${ }^{2}$ These promises were central to a 'creativity' discourse developed by policymakers, media commentators, academics, think tanks, etc., which increasingly defined creativity within the framework of technology and business, and more fundamentally, competition. ${ }^{3}$ Central to the creativity discourse was the claim that 'creativity' exemplified innovation, flexibility and the willingness to embrace change, and was thus a resource to be mobilised by business ${ }^{4}$ This creativity discourse established the 'creative worker' as an exemplary entrepreneurial figure who was innovative, flexible, adaptable and resourceful. ${ }^{5}$ How did this come to pass? Historical precedents existed around the figure of the artist during the Romantic period, a time when artists began to produce for a market rather than for aristocratic patrons, thus justifying the idea of competition as meritocracy. ${ }^{6}$ These ideas of the artist as exemplary figure and talent-as-meritocracy became common sense within popular conceptions of cultural work. In the 1960s, qualities represented by the figure of the artist became associated with the rejection of the rhetoric and tactics of the traditional left, in what Luc Boltanski and Eve Chiapello termed 'the artistic critique'. ${ }^{7}$ This represented a rejection of the 'organisation man and the public and private bureaucracies of the post-war period' and asserted 'a doit-yourself, work-for-yourself attitude that represented a powerful feeling of liberation' ${ }^{8}$ During the 1970s and 1980s, artistic discourses then were taken up within management theory (New Spirit of Capitalism). More recent policy debates positioned cultural work in relation to both entrepreneurialism and progressive politics. In the US, Richard Florida promoted the idea to urban planners that attracting the 'creative class', and supporting progressive values (reflected in concepts such as the 'gay index') would boost local economies (Rise of the Creative Class). In connection with this, conditions which were common practice within cultural work (such as project-working, and selfemployment) were heralded as being at the forefront of economic, social and technological change). By contrast, other forms of employment (such as work in industry or in public sector professions) were seen to be rigid, inflexible and ultimately residual, within the context of post-industrialism. According to Justin O'Connor, such perspectives rested on the assumption that the destruction of manufacturing and the welfare state in industrialised countries were inevitable historical developments rather than the product of specific political actions and decisions ${ }^{9}$ as well as the distancing of the so-called creative class from the labour movement ('Intermediaries and Imaginaries', p9). It also accompanied the rhetoric around New Public Management under the New Labour administration that the state stifled the 'creativity, dynamism and competitiveness', which were seen to be intrinsic qualities of the free market. ${ }^{10}$ As Kate Oakley has argued, creativity within these policy

\footnotetext{
${ }^{2}$ Andy Pratt and Paul Jeffcutt, 'Creativity, Innovation and the Cultural Economy: Snake Oil for the 21st Century?', in A. Pratt and P. Jeffcutt, (eds), Creativity, innovation in the cultural economy, London, Routledge, 2009, p1.

${ }^{3}$ This has now been extensively critiqued; see Garnham, 2005; Peck, 2005; Lovink and Rossiter, 2007; and Hewison 2015 amongst others.

${ }^{4}$ John Howkins, The Creative Economy: How people make money from ideas, London, Penguin Books, 2001 and Charles Leadbeater, Living on Thin Air: The new economy, London, Penguin Books, 1999.

${ }^{5}$ Richard Florida, The rise of the creative class and how it's changing work, leisure, community and everyday life, New York, Basic Books, 2002 (Abbreviated to Rise of the Creative Class).

${ }^{6}$ Jerrold Siegel, Bohemian Paris: Culture, Politics and the Boundaries of Bourgeois Life, 1830-1930, John Hopkins University Press, Baltimore,1999, p15.

${ }^{7}$ Luc Boltanski and Eve Chiapello, The New Spirit of Capitalism, London, Verso, 2005 (Abbreviated to New Spirit of Capitalism).

${ }^{8}$ Justin O'Connor, 'The cultural and creative industries: a review of the literature', Report for Creative Partnerships, Arts Council England, 2007, p32, http://kulturekonomi.se/uploads/cp_litrev4.pdf.

${ }^{9}$ Justin O'Connor, 'Intermediaries and Imaginaries in the Cultural and Creative Industries', Regional Studies 49, 3(2015), p12 (Abbreviated to 'Intermediaries and Imaginaries')

${ }^{10}$ John Clarke and Janet Newman, The Managerial State: Power, Politics and Ideology in the Remaking of Social Welfare, London, SAGE, 1997, p45. Also see Paul Du Gay, In Praise of Bureaucracy: Webber, Organisation, Ethics, London, SAGE, 2000, p71.
} 
discourses became reframed as 'problem solving', as 'the application of knowledge and skills in new ways to achieve a valued goal', rather than via 'notions of fantasy, play or uselessness'

conventionally associated with the arts. This tendency was also reflected in higher education, where an increasingly instrumental conception of creativity as skills and technological competencies became dominant. $^{12}$

The increasing popularity of 'social innovation' as a fashionable policy term was consistent with these developments. 'Social innovation', coined by Geoff Mulgan, CEO of the Young Foundation, is commonly defined as 'new ideas (products, services and models) that simultaneously meet social needs and create new social relationships or collaborations'. ${ }^{13}$ According to Sebastian Olma, the term 'innovation', as it is often conceived, does not mean any new idea, but carries strong associations of business and technology, and so new ideas become by definition entrepreneurial ideas. ${ }^{14}$ Social innovation is thus very similar to creativity-as-problem-solving as flagged up by Oakley; and Olma warns of its tendencies to what Evgeny Mozorov terms 'solutionism', or approaching complex social problems as simple technological problems to be solved ('Rethinking Social Innovation'). Other critiques of 'social innovation' include its mobilisation of the ingenuity of ordinary citizens as a resource that can be used to shift responsibility from the welfare state onto individuals and the private sector, who are then encouraged to 'make do with less' ('Social Innovation on the Rise', p8). This particular concept (that the creativity of citizens can take the place of public investment)has had particular consequences under austerity, which I will now discuss.

\section{Austerity and the Big Society}

This celebration of the entrepreneurial creative worker was popularised before the financial crisis, when easier claims could be made for the creative industries boosting economic growth. However, the concept of creativity has also played a role within the austerity context in justifying the outsourcing of public services to charities, mutuals and citizens' voluntary labour. I will first outline the austerity context and will then explore the discussion of creativity within grey literature by the National Endowment for Science, Technology and the Arts (Nesta), a UK charity promoting innovation in public service reform. As of 2015, the past few years have been marked by harsh austerity measures, several years of economic stagnation ${ }^{15}$ followed by a precarious and unstable recovery ${ }^{16}$ as well as the expansion of inequality that has seen both the shrinking of the middle class, and the rapid expansion of both the poor and the wealthy. ${ }^{17}$ Between 2010 and 2015, the Conservative-Liberal Democrat Coalition Government successfully attributed the financial crisis to the 'excessive spending' of the previous administration. Public spending fell to 40.5 per cent of national income, and at the time of writing, the Conservative government (now re-elected with a majority) has drawn up

\footnotetext{
${ }^{11}$ Kate Oakley, 'The Disappearing Arts: Creativity and Innovation After the Creative Industries', International Journal of Cultural Policy, 15, 4 (2009), p405 (Abbreviated to 'Disappearing Arts').

${ }^{12}$ Philip Ramsey and Andrew White, 'Arts for Arts' Sake: A Critique of Instrumentalism in the Teaching of Media and Communications in UK Universities’, International Journal of Cultural Policy, 21, 1 (2015), pp7896.

${ }^{13}$ Francesco Grisiola and Emmanuele Ferragina, 'Social Innovation on the Rise: Yet Another Buzzword in the Time of Austerity?', Salute e Societa, 1 (2015), p1 (Abbreviated to 'Social innovation on the rise').

${ }^{14}$ Sebastian Olma, 'Rethinking Social Innovation between Imitation and Invention', Institute of Network Cultures, 18 August 2014, http://networkcultures.org/mycreativity/2014/08/18/rethinking-social-innovationbetween-invention-and-imitation.

15 William Keegan, 'When recovery follows austerity, it is not cause and effect', The Guardian, 4 May 2014, http://www.theguardian.com/business/2014/may/04/recovery-austerity-cause-effect-george-osborne [accessed $1 / 8 / 2015]$.

16 James Meadway, 'This isn't an economic recovery, it's a relapse', New Economics Foundation, March 19 2014, http://www.neweconomics.org/blog/entry/this-isnt-an-economic-recovery-its-a-relapse [accessed $1 / 9 / 2015]$.

${ }^{17}$ Benjamin Hennig and Danny Dorling, 'The hollowing out of London: How poverty patterns are changing', New Statesman, 13 March 2015, http://www.newstatesman.com/politics/2015/03/hollowing-out-london-howpoverty-patterns-are-changing [ accessed 15/7/2015].
} 
plans to further reduce it to 35.2 per cent of national income, its lowest level since $1948 .{ }^{18}$ According to the Institute for Fiscal Studies, local authority funding was cut by 23.4 per cent between 2009-2010 and 2014-2015. ${ }^{19}$ The costs of austerity have been mostly borne by low-income people, who are disproportionately affected by tax credit and benefit cuts. ${ }^{20}$

With the exception (at the time of writing) of the election of Jeremy Corbyn as leader of the Labour Party, challenges to austerity have to date been relatively modest, both in terms of alternative arguments and in terms of social movements. More recently, inequality has entered public debate through the publication of books such as The Spirit Level by Richard Wilkinson and Kate Pickett in 2010 and Capital in the $21^{\text {st }}$ Century by Thomas Pilketty in 2014. In the US, the Occupy Movement mobilized around the slogan of 'we are the 99\%'; in the UK there have been public protests, notably the tuition fee protests in 2010, local anti-austerity campaigns, one-day strikes and marches by unions, and more recently housing campaigns such as Focus E15. ${ }^{21}$ However, these developments have yet to transform into large-scale social movements and it is unclear how much they have significantly shifted public opinion.

One of the challenges faced by resistance to austerity is the Conservatives' successful co-option of libertarian critiques of the welfare state. For example, their 2010 election campaign drew on such libertarian imagery, as in a billboard reading 'social revolution not state control'. These were combined with neo-communitarian arguments about how the state had become too distant from people's lives, and proposing the involvement of citizens in the running of public services. The term 'The Big Society' was coined by Conservative Party strategist Steve Hilton, ${ }^{22}$ bringing together 'communitarian conservatism and libertarian paternalism'. ${ }^{23}$ The key principles of the Big Society were also set out by the book Red Tory, in which Philip Blond, Conservative political philosopher and director of the ResPublica think tank, proposed that public services should be based on the model of social enterprises and mutuals such as John Lewis ${ }^{24}$ thereby 'harnessing two powerful forces: the insight and dedication of front-line workers, and the engagement of citizens and communities' (Red Tory, p239). Blond claimed that such models of public service provision would both unleash creativity and restore a lost sense of community.

Since the onset of the financial crisis and the election of the Coalition government, there has been much public debate around the purpose of public services, due both to reductions in public spending and their characterisation as top-down, technocratic and unresponsive to public needs. Within this context, austerity came to be seen as an opportunity both to foster creativity and restore a missing citizen engagement. This perspective will now be explored through grey literature from the Nesta think tank, which was central to the creative industries discourse under New Labour; ${ }^{25}$ after the

${ }^{18}$ Institute for Fiscal Studies, 'This government has delivered substantial spending cuts; big differences in parties' plans for next parliament', 13 May 2015, http://election2015.ifs.org.uk/public-spending [acessedc $1 / 6 / 2015]$.

${ }^{19}$ Institute for Fiscal Studies, 'Sharpest cuts to local government spending in poorer areas; same areas likely to lose most in next few years', 6 March 2015, http://election2015.ifs.org.uk/article/sharpest-cuts-to-localgovernment-spending-in-poorer-areas-same-areas-likely-to-lose-most-in-next-few-years [accessed 20/7/2015].

${ }^{20}$ Centre for Welfare Reform, Counting the Cuts, 2014, http://www.centreforwelfarereform.org/news/countingthert-published/00141.html [accessed 1/8/2015].

${ }^{21}$ The Focus E15 campaign organised by a group of young mothers in East London in response to the closure of the Focus E15 shelter for young homeless people.

${ }^{22} 10$ Downing Street, 'Government Launches Big Society Programme', gov.uk,18 May 2010,

https://www.gov.uk/government/news/government-launches-big-society-programme [accessed 1/6/2015].

${ }^{23}$ Alan Walker and Steve Corbett, 'The "Big Society", Neoliberalism and the Rediscovery of the Social in

Britain', Sheffield Political Economy Research Institute, 2013, http://speri.dept.shef.ac.uk/2013/03/08/bigsociety-neoliberalism-rediscovery-social-britain/ [accessed 1/5/2015].

${ }^{24}$ Philip Blond, Red Tory: How the Left and Right have broken Britain and how we can fix it, London, Faber\&Faber, 2010 (Abbreviated to Red Tory).

${ }^{25}$ Kate Oakley et al, 'The national trust for talent? NESTA and New Labour's cultural policy', British Politics 9 (2014), pp297-317. 
change in government Nesta became involved with a series of initiatives on public service reform. Nesta commissioned a project in 2011 entitled People Powered Public Services, which was based on the principle that the public should play a greater role in the running of public services: ${ }^{26}$ they also administer a $£ 14$ million 'innovation fund' in connection with the Cabinet Office for Social Action, which is about integrating volunteers into the running of public services. ${ }^{27}$ The People Powered Public Services blog by Nesta Chief Executive Philip Colligan spelled out the project philosophy:

Our narrative around public services reform starts with the need to move from a paternalistic model of public services where they are "done to" people, to a more collaborative approach where people are involved in the design and delivery of the services that they rely on. This isn't about austerity, although that accelerates the need for change (my emphasis). What it's really about is a recognition that the public services bequeathed to us by our great grandparents aren't up to the challenges of the $21 \mathrm{st}$ Century ('People Powered').

Colligan calls for greater public involvement 'in the design and delivery' of public services (notably, without explaining how people will find the time, or if they will be compensated for their efforts). Nesta's recommendations from their Creative Councils project, entitled A Call for Action: Ten Lessons for Local Authority Innovators by Sophia Parker and Charles Leadbeater (the latter has a long history with Nesta) ${ }^{28}$ stated that 'the challenges of austerity and rising demands, combined with the potential of new technologies, have spurred a new wave of civic entrepreneurialism'. ${ }^{29}$ The authors also characterized a 'creative council' as a 'resilient council', displaying the very same qualities as a resilient individual: adaptable, capable of withstanding disruption, and more importantly, making do with less. The Big Society and the Nesta proposals are very similar to the discussion of social innovation, but crucially, also combine libertarian and neo-communitarian approaches.

\section{Austerity as restoring a lost sense of community}

I will now examine the wider appeal of these ideas, beyond policy circles, and in particular the notion that austerity both enables creativity and restores of a lost sense of community. This perception draws on aspects of the environmental movement, ${ }^{30}$ as well as protectionist critiques of globalisation, and in particular concerns that it has caused alienation, disruption and loss of local identity. ${ }^{31}$ Greg Sharzer has also explored this phenomenon more critically in No Local, where he examines the assumption behind localism that the problems of capitalism are largely those of scale (No Local, p8) and that scaling down would solve the complexities of globalised capitalism and also restore a lost sense of community (No Local, p20). There has been a long history of perceiving community as lost and as in need of restoration. In Against the Romance of Community, Miranda Joseph defines community as a 'Romantic discourse' in which community is positioned as prior in time to 'society', for which we 'yearn nostalgically from our current fallen state of alienation, bureaucratization, and rationality'. ${ }^{32}$

\footnotetext{
${ }^{26}$ Philip Colligan, 'People Powered Public Services in Practice', Nesta, 13 February 2014, http://www.nesta.org.uk/blog/people-powered-public-services-practice [accessed 1/8/2015] (Abbreviated to 'People Powered').

${ }^{27}$ Nesta, Centre for Social Action Innovation Fund, n.d., http://www.nesta.org.uk/project/centre-social-actioninnovation-fund [accessed 1/8/2015].

${ }^{28}$ Leadbeater has written publications for Nesta since 2006; and is currently a Fellow of the organisation.

${ }^{29}$ Sophia Parker and Charles Leadbeater, A Call for Action: Ten Lessons for Local Authority Innovators, Nesta/LGA Creative Councils, November 2013, p5, http://www.nesta.org.uk/sites/default/files/creative_councils_10_lessons.pdf

${ }^{30}$ Rebecca Bramall, The cultural politics of austerity: past and present in austere times, Basingstoke. PalgraveMacmillan, 2013.

${ }^{31}$ Shumacher 1999 cited in Greg Sharzer, No Local: Why Small-Scale Alternatives Won't Change the World. Winchester Zero Books, 2012 (Abbreviated to No Local).

${ }^{32}$ Miranda Joseph, Against the Romance of Community, Minneapolis, University of Minnesota Press, 2002, p1 (Abbreviated to Against).
} 
Joseph characterises community's relationship to capitalism as supplementary, drawing on Derrida's theorisation in Of Grammatology (Against, p3). She interprets the supplement in the following terms:

The structure constitutively depends on something outside itself, a surplus that completes it, providing the coherence, the continuity, the stability that it cannot provide for itself, although it is already complete. But at the same time, this supplement to the structure supplants that structure; insofar as the structure depends on this constitutive supplement, the supplement becomes the primary structure itself; its own logic becomes, or at least may become, dominant or destabilizing, a blockage to the continuity, a sign of crisis or incompleteness (Against,p3).

According to Joseph, 'community' functions as a supplement to capitalism because it is positioned as its other or opposite, but also as having the capacity to balance and humanise capitalism (Against, p3). Because 'community' is seen as an 'other' to capitalism, but is deeply imbricated within it, it has a particular insatiable dynamic of loss, as efforts to restore a missing sense of community will always fall short (the present will always feel artificial compared to the past). It is the logic of an unfulfillable desire, making it very easy for corporations and politicians to exploit. As Jeremy Gilbert argues in Common Ground, all UK opposition parties (on both the Right and the Left) 'have almost invariably made some promise to restore an apparently lost sense of community to British public life', suggesting that there is easy political capital to be made in appealing to such nostalgia. ${ }^{33}$ The narrative of lost community is ultimately a pessimistic one, leaving little room for agency. Similarly, as Sharzer has argued, localism is based on the premise of the impossibility of larger-scale social change (No Local, p3).

However, it would be problematic to dismiss these desires for community entirely as sentimentality, given the deeper underlying suspicion that something real has been lost, which is why politicians continue to appeal to a lost community. Ruth Levitas argues that we need to consider projects such as The Big Society in relation to genuine concerns, rather than dismissing them entirely as false consciousness. ${ }^{34}$ She argues that 'only such an approach explains why discourses such as the Big Society have purchase among some of those whose interests are not served by Coalition policies' ('The Just's Umbrella', p330). Neo-communitarian commentators such as Blond believe that 'a revival of collective participation' can solve society's ills ('The Just's Umbrella', p334) but ignore the material conditions which make collective organization possible. Levitas observes that 'many of the conditions of working class organisation have been eroded [as they] depended on relatively stable work and relatively stable local or work-based communities: social policies from Thatcher on have undermined these material bases of self-organisation, resilience and sociality' ('The Just's Umbrella', p334). Similarly, Angela McRobbie has observed that the decline of social democracy and the debates around the politics of social welfare is 'strangely unmarked and hence unmourned'. ${ }^{35}$ Janet Newman and John Clarke also argue that the state can no longer embody a unified form of public interest or a singular public, and that ' $[t]$ he social and political settlements on which earlier forms of the state rested have now unravelled' ${ }^{36}$ Although the financial crisis has led to a renewed focus on the need for stability in the face of economic uncertainty, there is also now widespread disenchantment with the state, reflecting 'the experience of the kind of state we currently have to live with' which has been 'commodified, marketised and managerialised, and seems to ignore the human relationships at stake in its encounters with citizens'('States of Imagination', p1). The search for new forms of political and social engagement which mark new social movements (Clarke and Newman give the example of the

\footnotetext{
${ }^{33}$ Jeremy Gilbert, Common Ground, London, Pluto Press, 2013, p162.

${ }^{34}$ Ruth Levitas, 'The Just's Umbrella: Austerity and the Big Society in Coalition Policy and Beyond', Critical Social Policy, 32, 3 (2012), p332 (abbreviated to 'The Just's Umbrella').

${ }^{35}$ Angela McRobbie, 'Feminism, the family and the new mediated maternalism', New Formations 80 (2013), p126.

${ }^{36}$ John Clarke and Janet Newman, 'States of Imagination', Kilburn Manifesto, 2015, p7 (Abbreviated to 'States of Imagination').
} 
Indignados in Spain) do not see the state as a worthwhile site for political imagination or struggle. This means that the role of the welfare state is rarely addressed in relation to these discussions of community or its loss. The erosion of the conditions which enable collective organization, combined with the loss of interest in the welfare state as a political project, thus cannot be entirely dismissed as nostalgia for an idealized past. Because the welfare state is not generally seen to enable participation, it makes it easier for commentators such as Blond to argue that the welfare state impedes citizen engagement.

What this reveals is that 'community' is invoked in various, often contradictory ways, for different political purposes, which do not map easily onto the political spectrum. The idea of community as nostalgia has been discussed as something which has been lost and which needs to be restored. In some cases this is about romanticising a lost golden era but in other cases mourning a genuine loss of sociality - one which may have previously functioned as a resource for alternative values which could enable mobilization against neoliberalism. It is not always easy to determine whether claiming a sense of community has been lost is one or the other: a real sense of loss, or an inability to recognize current forms of sociality and community which do not fit our preconceptions? Equally, the linking of community to place (a commonsense connection which is taken for granted) can also serve different political purposes. Community as place can counter the homogenizing tendencies of globalization, but can also be used to assert parochial and exclusionary conceptions of belonging and cultural identity. It is also important to question who has access to a stable relationship to place (implied by the term 'community') within a globalized economy in which people are expected to move to another city or even country in search of work, or become displaced from low-income neighbourhoods due to gentrification. For those who are forced to be mobile, does community-as-place become a luxury, reserved for those with mortgages and stable incomes?

As mentioned, this does not map neatly onto the political spectrum. There have been nostalgic and communitarian currents within both the Left and the Right, as Stuart Hall has explored in many of his writings during the 1970s and 1980s, in which he critiqued 'traditionalism' (taken to mean social conservatism in general and a regressive position on issues of gender, race and sexuality in particular) within both Thatcherism and the orthodox Left. As Jeremy Gilbert has pointed out, the Conservatives appealed to 'national togetherness' in John Major's 1992 election campaign, and communitarian thinkers such as John MacMurray and Amitai Etzioni were influential on Tony Blair's thinking. ${ }^{37}$ This pattern has continued, both with the 'Big Society' discussed earlier, as well as through former Labour Leader Ed Miliband's appeal to Victorian Conservative Prime Minister Benjamin Disraeli's concept of 'one nation', 'making an explicit virtue of its deliberate conservatism' (Common Ground, p163). More recently, post-liberal commentators such as David Goodhart - who notably does not frame his position as right-wing - have argued, disturbingly, that a plural, multicultural society such as the UK is incompatible with a functioning welfare state. ${ }^{38}$ This illustrates Gilbert's warning that 'community' can often mean 'a form of collectivity which is dependent upon a shared, but static homogeneous identity'(Common Ground, p164). In the aftermath of the financial crisis, there is a sense that one is left with two bad choices: neoliberal individualism, or conservative conceptions of community, reflecting the extent to which the current conjuncture is also a political crisis. Other alternatives seem much more difficult to imagine - although Gilbert argues both for their indispensability to progressive politics and for their urgency (Common Ground, p216). All this suggests the importance of considering what is stake when the need to restore a lost sense of community is invoked, and the importance of thinking about the role of the welfare state in relation to such appeals to community. The following section will explore these questions in relation to the case of the libraries in Lewisham.

\section{Anti-austerity campaigns in Lewisham}

\footnotetext{
${ }^{37}$ Jeremy Gilbert, Common Ground, London Pluto Press, 2014, p162.

${ }^{38}$ David Goodhart, British Dream: Successes and failures of post-war immigration, London Atlantic Books, 2013.
} 
In the rest of the article, I will examine how these dynamics played out in a campaign to save five libraries in Lewisham ${ }^{39}$ in 2010-11, and how 'creativity' and 'community' were mobilised within the campaign.,. I will focus on the response of campaigners to the takeover of three of the libraries by Eco-Computers (a social enterprise), and one by the Age UK charity. The takeover of New Cross library by a charity, Bold Vision will then be explored. I was involved in these campaigns as an activist within the Lewisham Anti-Cuts Alliance (LACA), and worked with some of the key campaigners. I will first reflect on the role of LACA and my involvement. I will then discuss the campaign developments chronologically, including the takeover of New Cross Library by Bold Vision, and its rebranding as New Cross Learning, in order to examine how "creativity" and "community" were articulated. The case study is based on interviews with three key activists in the campaign, auto-ethnographic reflections on my involvement as an activist, as well as an analysis of Social Enterprise London's pamphlet on social enterprise-run libraries and New Cross Learning's promotional video.

Many local anti-cuts campaigns were quickly established in the immediate aftermath of the election of the Coalition Government. From the autumn of 2010 to the summer of 2011, I became involved in the LACA because I was concerned about how cuts would affect my local area. LACA organized local campaigns together with People Before Profit (a local campaign group and political party who stands in council elections on an anti-privatisation platform), Keep our NHS Public, and other local groups in the area. According to one of the activists interviewed, LACA was able to bring people together in a way that was relatively non-sectarian and open-minded, some of whom worked together on campaigns later on. ${ }^{40}$

However, the LACA meetings were also often fraught (symptomatic, in retrospect, of many of the impasses of the Left). in part this was due to a culture clash between two activist cultures. Some of the activists were interested in creative tactics, and a more horizontal structure. Others, mostly members of Trotskyist political parties, had known each other for a long time, and held quite rigid ideas of organisational tactics: stalls, marches and support for strikes were favoured whilst direct action tactics and the use of social media were viewed with suspicion (meaning they were unwilling to help maintain the blog and email list, leaving to myself and a few others).There was also some confusion and conflict about which campaigns should be supported. In retrospect, this may have been based on conceptions of the industrial working class as privileged revolutionary subject, problematic given both Lewisham's economy, in which a significant percentage of the population are employed by the council,${ }^{41}$ as well as the relative lack of union activity at the time, particularly from UNISON, who represented many of the council employees. Those who attended the meetings tended to be white and middle-aged or older, and rather unrepresentative of the population of a borough in which two out of five local residents are from a black or minority ethnic background. ${ }^{42}$ Occasionally, curious people would attend the meetings who I had not seen before, but would never return.

The Labour Party in Lewisham played a very contradictory role in their relationship to the cuts, which affected LACA's activities. The Labour Party held a majority in the local council and at the time of writing holds 53 out of 54 council seats. ${ }^{43}$ According to one of the activists interviewed, many local residents voted Labour because they felt that they would be a kind of insurance against the cuts from the Conservatives. ${ }^{44}$ These conditions produced a situation where the council did not have to be accountable to their own constituents and seemed unused to being challenged by them. One of the

\footnotetext{
${ }^{39}$ The libraries were Blackheath Library, Crofton Park Library, Grove Park Library, New Cross Library, and Sydenham Library.

${ }^{40}$ Activist \#3, interview 20 February 2015 (Abbreviated to Activist \#3).

${ }^{41}$ Lewisham Strategic Partnership, About the Borough, n.d., http://www.lewishamstrategicpartnership.org.uk/borough.asp [accessed 15/7/2015].

${ }^{42}$ Lewisham Joint Strategic Needs Assessment, Ethnicity, c.2012, http://www.lewishamjsna.org.uk/a-profile-oflewisham/social-and-environmental-context/ethnicity [accessed 1/8/2015].

${ }^{43}$ London Councils, 2014 Borough Election Results: London, 2014, http://www.londoncouncils.gov.uk/londonfacts/elections2014/boroughs/lewisham [accessed 15/8/2015].

${ }^{44}$ Activist interview \#2, interview 13 February 2015 (Abbreviated to Activist \#2).
} 
activists interviewed saw the cuts as 'essentially an issue of failed democracy'. ${ }^{45}$ However, the local Labour Party also treated local anti-cuts activism as a potential threat to their credibility in the borough as the only voice of social justice, and thus their electoral prospects. This placed them in the contradictory situation of both implementing the cuts, and simultaneously campaigning against them, leading local activists to suspect they were using their involvement in local campaigns to manage dissent.

\section{A "Big Society" solution for the libraries}

In the summer of 2010, Lewisham Council announced that they were going to close five of the libraries in the borough. The borough of Lewisham measures $35.15 \mathrm{~km}^{2}$ (an average size in comparison to other inner London boroughs) and has a population of 275, 885 according to the 2011 census $;{ }^{46}$ Lewisham is the $31^{\text {st }}$ most deprived local authority out of the 351 local authorities in England. ${ }^{47}$ Prior to 2010, the borough had thirteen libraries. The announcement to close the libraries represented the first round of cuts after the 2010 election. ${ }^{48}$ This caused a fairly large and high-spirited campaign around saving the libraries to mobilise quickly, according to one local activist, as local groups set up to resist the closures, petitions, involving 'people who had never been involved in political things before' (Activist \#2).

The campaign consisted of marches, protests at council meetings, a petition that attracted thousands of signatures and demonstrations outside the Department for Culture, Media and Sport (the relevant UK government department, based in central London). There was support from national campaigns, such as Voices for The Library. ${ }^{49}$ Billed as a "carnival", a march to the council chambers in October 2010 drew hundreds of demonstrators. As mentioned, the presence of Labour councillors and MPs within the campaign was controversial, as they were seen by many as responsible for the decision to close the libraries.

Despite this opposition, in May 2011 the council made the decision to stop operating the libraries and transfer them to charities and social enterprises with volunteers replacing librarians, with New Cross still set to close. ${ }^{50}$ This decision was very contentious at LACA. Some argued for the importance of defending publicly funded services and that closure would be preferable to the spread or normalisation of volunteer-run public services. Others believed, pragmatically, that transfer was better than nothing. One activist summarised the second approach:

I think it's better to keep a facility open even with volunteers than for it to close, because it's much harder to reopen it again later ... There were people who didn't think it was right for the libraries to be run by volunteers and I think you can be too purist. I think... it's worth trying to keep something open so you can get it back into public financing later on (Activist \#2).

This reflects the difficult choices facing many campaigners: between closure and keeping the libraries open under compromised circumstances. In practice, according to one of the activists interviewed, the libraries turned over to Eco Computers functioned only partly as libraries: one became a café, with

\footnotetext{
${ }^{45}$ Activist interview \#1, interview 13 February 2015 (Abbreviated to Activist \#1).

${ }^{46}$ Lewisham Council, 2011 Census Second Release, 2012, http://www.lewisham.gov.uk/inmyarea/Documents/2011CensusSecondReleaseDec2012.pdf [accessed $15 / 8 / 2015]$.

${ }^{47}$ Lewisham Joint Strategic Needs Assessment, Index of Multiple Deprivation, c.2010, http://www.lewishamjsna.org.uk/health-inequalities/index-of-multiple-deprivation [accessed 9/2015].

${ }^{48}$ News Shopper, 'Lewisham: library futures to be discussed at meeting', News Shopper 21 July 2010, http://www.newsshopper.co.uk/archive/2010/07/21/8284279.LEWISHAM Library futures to be discussed at meetings/ [accessed].

${ }^{49}$ Voices for the Library, http://www.voicesforthelibrary.org.uk [accessed 1/9/2015]. 50 Lewisham Council, Meeting minutes, Library Service - asset transfer proposals and provision of community library facilities, 6 May 2011, http://councilmeetings.lewisham.gov.uk/mgAi.aspx?ID=1427 [accessed $1 / 9 / 2015]$.
} 
another being used primarily for recycling computers with some space for libraries, and with the branding of the social enterprise quite prominent (Activist \#2).

This model has since become more widespread, as figures suggest there are now close to 250 volunteer-run libraries in the UK. ${ }^{51}$ Unsurprisingly, such developments are heralded as largely positive by Social Enterprise London, an agency for supporting social enterprise (since incorporated into Social Enterprise UK). SEL published a report entitled Libraries in Transition: Are there creative alternatives?, which presented social enterprise as the solution for underfunded libraries but also, crucially, asserted that unlike those run by social enterprises, libraries operated by local authorities are 'in communities but not of communities'. ${ }^{52}$ This claim was never substantiated by any evidence (the accompanying descriptions of social enterprises simply outline their mission statements and describe their activities, but do not discuss results). The pamphlet articulates several key claims: that this approach is creative ('a creative new alternative') (Libraries in Transition, p2) and has an organic relationship to communities - that libraries will become 'much more central to the lives and needs of local people'(Libraries in Transition, p2) - and that it is good for society because it provides voluntary and employment experience and skills training (Libraries in Transition, p5) and furthermore that spending cuts provide an opportunity as 'in an era of reduced public spending they are well-placed to succeed' (Libraries in Transition, p6).The claims for such an approach to public service as both more creative and more conducive to community engagement (the assumptions behind Libraries in Transition as well as the Nesta proposals discussed earlier) suggest deeper ideologies about creativity in relation to the welfare state and also asserts that a sense of community is lacking and in need of restoration. It may also reflect the ubiquity of community economic development as a dominant model for public service provision, particularly within Canada, the US and the UK, which, according to James De Filipis et al., has 'been accompanied (and accomplished) by a focus on the community in-and-of itself' and has been mirrored by a 'diminished set of critical political perspectives'. ${ }^{53}$

On a practical level, questions have also been raised about the effectiveness of public services operated by charities. Concerns about leisure trusts ${ }^{54}$ were raised by the European Services Strategy Unit (ESSU) charity in a report entitled The Case Against Leisure Trusts. Drawing on data from the Audit Commission, ESSU pointed out that the quality of services provided by trusts was 6-10 per cent lower than those delivered by local authorities. ${ }^{55}$ ESSU also questioned the financial stability of trusts as they lack the surpluses and the economies of scale of local authorities (Case Against Leisure Trusts, p4) with risks still retained by the local authorities. Workforces employed by leisure trusts experience the casualisation and lack of trade union recognition endemic to the private sector (Case Against Leisure Trusts, p5). ESSU also questioned the claims that are made about reinvigorating local democracy, citing examples of lack of consultation with users and sports clubs, and limited control of councillors over facilities sector (Case Against Leisure Trusts, p6). Similar concerns have been expressed about the viability of social-enterprise run services; a report by Social Enterprise UK also pointed out that social enterprises lack the resources to compete against large for-profit companies such as Serco or G4S, which are treated by government as "too big to fail" ${ }^{56}$ The most contentious

\footnotetext{
${ }^{51}$ Public Libraries News, List of Volunteer Run Libraries, n.d., http://www.publiclibrariesnews.com/aboutpublic-libraries-news/list-of-uk-volunteer-run-libraries [accessed 1/8/2015].

52 Social Enterprise London, Libraries in Transition: Are there Creative Alternatives? Public Service Hub 2020 at the RSA, 2011, p2, http://www.rsa2020publicservices.org.uk/publications/libraries-in-transition-are-therecreative-alternatives/ [accessed 1/9/2015] (Abbreviated to Libraries in Transition).

${ }^{53}$ James De Filippis et al, 'What's left in the community? Oppositional politics in contemporary practice', Community Development Journal 44,1 (2009), p38.

${ }^{54}$ A leisure trust is a particular type of charity which was set up to manage leisure centres and other sports facilities, and which were created as part of a process of outsourcing municipally provided services).

55 European Services Strategy Unit, The Case Against Leisure Trusts, 2008, p3, http://www.european-servicesstrategy.org.uk/news/2008/leisure-trusts-briefing/leisure-trusts-briefing.pdf. (Abbreviated to Case Against Leisure Trusts).

${ }^{56}$ Social Enterprise UK, Out of the Shadows, 2013, p3, http://www.socialenterprise.org.uk/uploads/files/2013/10/out_of_the_shadows_report.pdf [accessed 15/8/2015].
} 
aspect of social enterprise-run public services has been the replacing of paid staff with volunteers, and the difficulty this poses for deprived neighbourhoods where people have little free time, and cannot reasonably be expected to provide the same level of expertise and reliability trained librarians.

\section{Austere creativity and the fate of New Cross Library}

In early 2011, New Cross Library was still under threat of closure; in response, an occupation took place at the library on 5 February 2011 for one night, in which many local campaigners participated, including myself. The occupation coincided with Save Our Libraries Day, a national day of action in defence of libraries, which included 80 'Read In' events by authors. ${ }^{57}$ The occupation began with a series of public readings in New Cross Library, after which we then refused to leave the building and held the library door open. The occupation led to the national campaign receiving significant media attention.

A compromise was eventually struck in which the library was turned over to volunteers, who would run it unpaid, but who also be responsible for the rent and utilities; the library was renamed 'New Cross People's Library'. During the brief transitional period when the library was not run by any established organisation, some activists felt that this could provide an opportunity to envision the library as a radical space (rather like an activist social centre), rather than as a library in the conventional sense, arguing that it had been a rather depressing space when it was run by the council. However, these possibilities never materialised because New Cross People's Library was turned over to Bold Vision and rebranded 'New Cross Learning', which according to one of the activists interviewed was because Bold Vision had credibility as an organization and an established reputation in the area (Activist \#2).

However, another activist I interviewed was more cynical about the role of Bold Vision, characterising them as 'a bit of a middle class charity, they want to do stuff down in the rough bit' (Activist \#1). The council eventually decided to charge peppercorn rent, but according to another activist (who was now involved with the running of the library), the space was being subsidized by the council as a matter of principle:

It's subsidised and supported by the council and the councillors, but not only that, they love it, they like to talk about how they helped [out] the library (Activist \#1).

Similar to Private Finance Initiatives, the conversion could potentially end up costing the local authority more, but because of the ideological commitment to the principle of transfer, it will likely be perceived as both an innovation and a success regardless of any risks or failings. The claims of SEL provide a framework for how the library conversion could be construed as successful, despite the fact that it is potentially both costly and carries a high risk of failure.

The claims made in New Cross Learning's promotional video were consistent with those made by SEL: being embedded in the community and providing skills training. There were several assertions about how New Cross Learning was serving the community: 'the community came together'; 'we live here so we know people by their first names', presenting the library as the 'glue which glues our community together' ${ }^{58}$ There were also testimonials from people who found jobs, describing how 'volunteers with no confidence come into a situation and find their feet... feeling they can participate in society again' (New Cross Learning). In the background were many shots of craft workshops: knitting classes, papier-mâché workshops, singing, 'baby bounce' classes (notably, nothing challenging or oppositional. These activities also embody what Nick Mahony and John Clarke have

\footnotetext{
${ }^{57}$ Kelly Smale, 'Group occupy New Cross Library in protest over closure threats', News Shopper, 5 February 2011 ,

http://www.newsshopper.co.uk/news/8835838.NEW_CROSS Group_occupy_library_in_protest_over threate ned_closure [accessed 15/8/2015].

New Cross Learning, Promotional video, 2013, http://www.youtube.com/watch?v=CdMy7GrmlME [accessed 1/8/2015] (Abbreviated to New Cross Learning).
} 
termed 'communitarian immediacy': people come together and communicate in an unmediated way which is seen to embody authentic experience. ${ }^{59}$ According to one of the activists who is now involved in New Cross Learning, 'they [Bold Vision] do good things for the community but it's what they think the community needs' and raised concerns about the lack of formal process for involving the community in decision-making (Activist \#1).

The question of who speaks for the community, and what the community needs is an important one. In the video one of the chairs of New Cross Learning said that 'Some people would like the council to run the library and get a qualified librarian. [But] the people who actually use the library would prefer it as it is', adding that 'we see these people every day and they trust us' (New Cross Learning). Another claimed that 'We're never going to go back to a small local library run by a librarian.' (New Cross Learning). Such statements raise questions about whether the community actually believes public libraries are really a thing of the past, and the extent to which they accept the necessity and inevitability of public service cuts. According to one of the activists interviewed:

[The chair of New Cross Learning] says, and I don't dispute it, that the library is much better than when the council ran it, so she doesn't want it to go back to being a council library, whereas our [campaign group's] policy is, well it's great that it's still open and it's run by volunteers but long-term we want it to be back in part of the library service and with paid staff (Activist \#2).

What does it mean to say that the 'library is better'? There were admittedly more cultural activities taking place at New Cross Learning than when it was run by the council (possibly reflecting lower priorities for such activities, or a lack of resources or both), but can this compensate for its uncertain funding situation? Another activist interviewed felt that such arguments were dangerous because it showed that running a library without paid staff was a sustainable option for cash-strapped local authorities (Activist \#3).

All activists interviewed described an incident where people were not allowed to hand out leaflets for Lewisham People Before Profit outside the library. The reason given was that the council would not approve, ironic given the council was no longer managing the library (Activists \#1 and \#2). They also mentioned that the key volunteers involved in running New Cross Learning were members of the Labour Party, and highlighted contradictions of setting up a volunteer-run library in response to cuts imposed by the Labour-run council. This raises questions about what sort of community space or creativity was being fostered, and if this depended on the avoidance of controversy, conflict and debate.

The fostering of (non-challenging) forms of creativity, combined with the exclusion of conflict and direct expressions of politics, can be seen as an example of what Kate Oakley calls the "'mainstreaming" of creativity, 'stressing its pro-social elements... excluding creative expression that is marginal, radical, counter-cultural or in some way deemed to be anti-social' ('Disappearing Arts', p405). It can also be interpreted as symptomatic of a particular depoliticised model of community development, which DeFilippis has characterised as 'neoliberal neo-communitarianism', based on the assumption of a conflict-free society devoid of power relations. DeFilippis traces its origins to the split between community development and community organising that occurred in the 1960s, and the rejection of the latter's association with radical politics. ${ }^{60}$ Within the austerity context, communities mobilise their creativity and resourcefulness to adapt to public service cuts, but do not have the space to ask why they are being made, let alone mobilise creativity towards the exploration of meaningful alternatives. In a wider sense this reflects what Gilbert sees as the difficulty under neoliberalism of putting creativity to work 'in a collective, political, democratic fashion' - more difficult than using it within individual, consumerist contexts (Common Ground, p212).

\footnotetext{
${ }^{59}$ Nick Mahony and John Clarke, 'Public crises, public futures', Cultural Studies 26, 14 (2013), p946.

${ }^{60}$ James De Filippis, Unmaking Goliath: Community Control in the face of Capitalism, London, Routledge, 2004, p56.
} 
The situation also raises larger questions about the role of the voluntary sector in public service provision within the austerity context. A secession of governments positioned the voluntary sector as an alternative provider of public services within a mixed economy, with consequences for its independence. ${ }^{61}$ Recent changes to funding arrangements (such as the replacement of grant aid with project-based contracts and 'payment by results') have made financing more precarious. ${ }^{62}$ Through legislation such as the Lobbying Bill, ${ }^{63}$ the government has limited the ability of charities to publicly criticize government policy. Within this context, charities are meant to be the upholders of social cohesion and civic responsibility and the defenders of dominant social and moral norms, but are not meant to undertake advocacy work or encourage meaningful democratic engagement. This places the voluntary and social enterprise sectors in an awkward position: of having to provide services, often on reduced budgets, possibly on a transitional basis (as they may ultimately be outsourced to for-profit corporations such as SERCO and G4S), with limited resources to engage citizens, or address the root causes (for example poverty, inequality, etc.) of the need for their services.

\section{Conclusion: is there a possibility for anti-austerity creativity?}

There are some difficult but important questions to be asked about why such models of public service provision develop and have (some limited) appeal within the austerity context. The campaign to save the Lewisham libraries was a defensive campaign, and was about preserving the status quo (functioning but severely underfunded libraries), and was marked by an underlying feeling, based on my conversations with other campaigners, that a win was unlikely because the council would not listen, so protest could only ever be symbolic. This may be due to wider public acceptance of the need for cuts. When leafleting for the library campaign, I frequently encountered people who had accepted that cuts must be made, or who argued that libraries had been made obsolete by the internet, or that if libraries were saved, then something else must be cut.

There are also difficult questions about why the LACA meetings were so counter-productive. In retrospect they were often fractious, involved rigid conceptions of campaigning, and were more concerned with point-scoring than doing practical organizing work. This could be understood as an example of what Wendy Brown termed 'left melancholy' in her classic essay drawing on Walter Benjamin's theorisation of the concept. She characterised this as:

a Left that has become more attached to its impossibility than to its potential fruitfulness, a Left that is most at home dwelling not in hopefulness but in its own marginality and failure, a Left that is thus caught in a structure of melancholic attachment to a certain strain of its own dead past, whose spirit is ghostly, whose structure of desire is backward looking and punishing. ${ }^{64}$

How else to interpret the infighting, point-scoring and sectarian manoeuvring that took place at these meetings? However, beyond clichés about boring meetings and the worst habits of the orthodox left, the campaign participants' conduct may also reflect the frustration at the lack of agency that citizens have in the face of decisions that have already been made and politicians who ignore their own voters. This sense of defeatism also marked the wider library campaign - possibly limiting its scope for success. Although initially hopeful and high-spirited, it did not sufficiently catalyse energy and creativity around an alternative, or communicate alternatives convincingly to the public. This impasse

\footnotetext{
${ }^{61}$ Jane Lewis, 'New Labour's Approach to the Voluntary Sector: Independence and the Meaning of Partnership', Social Policy and Society, 4 (2005), pp 121-131. Also see National Coalition for Independent Action, Fight or Fright: Voluntary Services in 2015, 2015, http://www.independentaction.net/wpcontent/uploads/2015/02/NCIA-Inquiry-summary-report-final.pdf.

${ }^{62}$ National Coalition for Independent Action, Fight or Fright: Voluntary Services in 2015, http://www.independentaction.net/wp-content/uploads/2015/02/NCIA-Inquiry-summary-report-final.pdf. ${ }^{63}$ UK Government, Transparency of Lobbying, Non-Party Campaigning and Trade Union Administration Act 2014, 2014, http://www.legislation.gov.uk/ukpga/2014/4/contents/enacted/data.htm [accessed 1/8/2015].

${ }^{64}$ Wendy Brown, 'Resisting Left Melancholia'. Boundary 2, 26.3 (1999), p26.
} 
may also be symptomatic of the defensive, single-issue orientation of anti-cuts campaigns, which, according to one of the activists, are difficult to transform into prefigurative experiments in democratic engagement (Activist Interview \#2). The campaign did not mobilise around libraries as what Jeremy Gilbert terms 'sites of collective joy' or as a commons (Common Ground, p201). The exceptions to these were the more imaginative and vibrant protest actions, such as the broad range of creative expression and the lively spirit of the march to the town hall or the occupation of New Cross Library. Such actions offered a fleeting glimpse of what an anti-austerity creativity might look like (creativity as the opening up of political space) however brief and ephemeral.

In the face of the melancholia and sectarianism of anti-austerity campaigns, projects such as New Cross Learning can appear as a creative model of community building (along the lines of that envisaged by SEL, Nesta and other organisations). This model is however one that accepts the principles of austerity and in fact sees austerity as an opportunity. It is precisely this form of creativity - in which the ingenuity of citizens becomes a resource to exploit in the absence of state funding, but do not have the autonomy to challenge the state's directives - that becomes central to the cultural politics of austerity. As the Lewisham case demonstrates, austerity promotes a particular form of creativity which is about resourcefulness and restoring what is seen to be a lost sense of community, but has little space for anything challenging or oppositional. It is reflective of a wider depoliticising dynamic in which problem-solving by individuals, charities and the private sector replaces political struggle or larger contestations; impulses towards self-organisation, instead of challenging the state, become mobilised to absolve it of responsibility.

However, one of the activists I interviewed saw the situation differently, characterising it as 'quite a painful process of the Left falling to bits and people who'd been in the Left for a long time coming to terms with that' (Activist \#3), 'the Left' in this case meaning the dogmatism and tactical conservatism which has been the legacy of left organisations. He said that the campaign to save Lewisham Hospital developed directly out of the relationships that had been developed through the library campaign and LACA (Activist \#3), as did a successful campaign to stop Lewisham council from selling off properties which involved squatting as a protest action, and creating links with the Focus E15 campaign in Newham (Activist \#3). Both involved imaginative tactics and a more open approach to organising. This can be understood as a more hopeful conception of creativity, one is not afraid of being oppositional or challenging, and which prefigures alternative futures.

As a point of comparison, it is worth considering the role of volunteer-run services in Greece (where austerity measures are much more severe), which Owen Jones described in his article on the 2015 election:

Outside one polling station, I speak to Georgia, who works at a hospital clinic manned by volunteers which caters for the impoverished. For unemployed Greeks denied access to the public healthcare system, such clinics are lifelines. Georgia has one clear ambition that after a year or two of a Syriza-led government, her clinic will no longer be needed and will close. ${ }^{65}$

The fate of Syriza (at the time of writing) has since become more uncertain. However, the significance of the clinic is that the provision of volunteer-run services and mutual aid systems is specifically intended as a temporary stopgap, and the goal is not to permanently institutionalize volunteer-run services (unlike with New Cross Learning). However, the volunteer-run clinic can be temporary precisely because it is part of a larger social movement which will hopefully create better healthcare provision, making volunteer-run clinics unnecessary in the future. This could be interpreted as an example of how the Big Society could be interpreted, through a utopian lens, as containing the seeds of 'another potential society' ('The Just's Umbrella', p336). As Ruth Levitas asks, 'what are the economic and social conditions under which these ideas would cease to be repressive, moralizing

\footnotetext{
${ }^{65}$ Owen Jones, 'Syriza's Victory: This is what the Politics of Hope Looks like', Guardian, 26 January 2015, http://www.theguardian.com/commentisfree/2015/jan/26/syriza-victory-lifted-greek-politics-cynicism-hope [accessed 15/7/2015].
} 
claptrap?'('The Just's Umbrella', p336). Levitas suggests that the answer involves rethinking what counts as production, wealth, and the quality of work (including the unpaid caring and educational work frequently carried out by women); and therefore calls for universal child benefit and a citizen's income ('The Just's Umbrella, p336).Such utopian thinking envisages a significant role for the welfare state, but also takes into consideration the critiques of postwar Keynesianism (such as its blind spot around the role of reproductive labour), and also engages with the questions around material conditions ignored by Blond, Nesta, SEL and others, particularly around who has time and energy to engage in volunteering. Rather than writing off the welfare or public service provision as a worthless site for political imagination or struggle, it is to engage in what Janet Newman and John Clarke call 'imaginaries of the state' ('States of Imagination', p7) of trying to re-imagine the function and purpose of the state, and its role in the making of publics' (States of Imagination, p8). Beyond official dialogues about the relationship between state and citizens, or political parties, Newman and Clarke note that rather than imposing a hegemonic vision (as in public relations 'listening exercises') this process needs to engage with a wide range of publics and foster the emergence of new ones (States of Imagination, p16), with their contradictory interests and desires. An anti-austerity creativity would engage in this sort of re-imagining process and the fostering of new publics, and would imaginatively consider and enact what alternatives might look like.

Biographical note: A researcher and activist, Kirsten Forkert is employed in the School of Media at Birmingham City University. She is currently writing a book on anti-austerity campaigns as part of Rowman \& Littlefield's Radical Cultural Studies series; she is also involved in Mapping Immigration Controversy, a collaborative project on Home Office communications. 